\title{
EFFECTS OF FOREST PLANTATIONS ON RAINFALL REDISTRIBUTION AND EROSION IN THE RED SOIL REGION OF SOUTHERN CHINA
}

\author{
Y. $\mathrm{CAO}^{1,2}$, Z. Y. OUYANG ${ }^{*}$, H. ZHENG ${ }^{1}$, Z. G. HUANG ${ }^{1}$, X. K. WANG ${ }^{1}$ AND H. MIAO ${ }^{1}$ \\ ${ }^{1}$ State Key Lab of Urban and Regional Ecology, Research Center for Eco-Environmental Sciences, \\ Chinese Academy of Sciences, P.O. Box 2871, Beijing 100 085, China \\ ${ }^{2}$ National Meteorological Centre, Beijing 100081, China
}

Received 29 January 2006; Revised 31 January 2007; Accepted 14 February 2007

\begin{abstract}
To evaluate the effects of different forest plantations on rainfall redistribution, we measured throughfall, stemflow, interception loss, surface runoff and soil loss from July 2004 to September 2005 in the three types of forest plantations Eucommia ulmoides, Vernicia fordii and Pinus massoniana. The results showed that differences in throughfall and stemflow between the three forest plantations were significant $(p<0 \cdot 05)$. Throughfall was highest in the V.fordii plantation and stemflow was highest in the E.ulmoides plantation. Throughfall plus stemflow below the E.ulmoides canopy was greater than that underneath the other forest types. Moreover, significant spatial variation in throughfall was observed. Throughfall in P.massoniana was $28.0-39.7 \%$ higher at a stem distance $<60 \mathrm{~cm}$ or $11.5 \%$ lower at a stem distance $>120 \mathrm{~cm}$ than in the other forests, but the difference was not significant between E.ulmoides and V.fordii. Moreover, the difference in throughfall at stem distances 60-120 cm was not significant between the different forest plantations. For E.ulmoides, throughfall under the peripheral crown part was $16 \cdot 1 \%$ higher than that close to the stem. In contrast to E.ulmoides, P.massoniana had $26 \cdot 8 \%$ lower throughfall under the peripheral crown part than close to the stem. No significant difference was found in throughfall for the various stem distances underneath V.fordii. Stemflow in E.ulmoides was 2-3 times higher than in the other forests $(p<0 \cdot 01)$. Interception loss accounted for $19.9 \%$ of gross rainfall for E.ulmoides, $20 \cdot 8 \%$ for V.fordii and $27 \cdot 2 \%$ for P.massoniana. Surface runoff and soil loss differed considerably among the three types of forest plantations. Annual runoff and total soil loss were lowest in the P.massoniana forest and highest in the V.fordii forest. This study indicated that P.massoniana, as a reforestation tree species, had the most positive effect on soil and water conservation among the three forest plantations. Copyright (C) 2008 John Wiley \& Sons, Ltd.
\end{abstract}

KEY WORDS: reforestation; throughfall; stemflow; interception; soil erosion; red soil

\section{INTRODUCTION}

Soil and water erosion was very severe in southern China because of the destruction of natural broad-leaf deciduous forests in the 1950s (Zhang et al., 2004). Reforestation served to control the serious soil erosion (Zhou et al., 2002a, 2002b). Recent concerns have focused on the impacts of the forest plantations on hydrological processes and soil erosion (Zhou et al., 2002b; Hanson et al., 2004). In this study, three tree species (Eucommia ulmoides, Vernicia fordii and Pinus massoniana) that were used frequently for reforestation in southern China were studied for their impacts on throughfall, stemflow and erosion at plot scale.

The objective of this study was to evaluate rainfall redistribution, surface runoff and soil erosion for the three forest types. Results from this study can be used by resource managers to select appropriate tree species for maximisation of hydrological benefits and also used to provide a scientific basis for protective reforestation.

* Correspondence to: Dr Z. Y. Ouyang, Research Center for Eco-Environmental Sciences, Chinese Academy of Sciences, P.O. Box 2871, Beijing 100 085, China.

E-mail: zyouyang@rcees.ac.cn 


\section{MATERIALS AND METHODS}

Description of the Study Area

The study was conducted at the Ecological Benefit Monitoring Station of the Yangtze River Protection Forest, located in Cili County, Hunan Province, China $\left(29^{\circ} 30^{\prime} \mathrm{N}, 110^{\circ} 10^{\prime} \mathrm{E}\right)$ (Figure 1). The station covers approximately $3.2 \mathrm{~km}^{2}$ of rugged hilly terrain, with altitudes varying between $210 \mathrm{~m}$ and $917 \mathrm{~m}$ a.s. 1. Climate of the study area is subtropical humid monsoonal. Mean annual precipitation is $1347.2 \mathrm{~mm}$, mean temperature is $28.5^{\circ} \mathrm{C}$ (absolute maximum of $38 \cdot 1{ }^{\circ} \mathrm{C}$ and absolute minimum of $-1 \cdot 0{ }^{\circ} \mathrm{C}$ ), and mean atmospheric humidity is around $83 \%$.

Soils are developed in arenaceous shale with soil texture of $66 \%$ sand, $19 \%$ silt, and $15 \%$ clay and distributed widely in southern China (Zhao, 2002). In the Chinese Soil Taxonomy, soils are classified as fine loamy, hyperthermic, acidic, Udic Cambisols (i.e. Haplic Alisols in FAO Taxonomy) (Gong, 1999). Chemical and physical characteristics of soils are shown in Table I. E.ulmoides, V.fordii and P.massoniana are dominant native tree species, and Cinnamomum camphora, Cunninghamia lanceolata and Citrus reticulata are subordinate native species within the study region. In this study, we selected E.ulmoides, V.fordii and P.massoniana as three main types of forest plantations, of which the stands account for $82.5 \%$ of the total area of reforestation. Moreover, about $80.0 \%$ of these forest plantations are located on a slope of $17-25^{\circ}$ in the study region. In each forest plantation established during 1986 and 1987, a plot was established measuring 400-500 $\mathrm{m}^{2}$. Soils had been cultivated before plantation but not after plantation establishment. Moreover, no chemical fertilizers were used in these plantations. Table II lists the averages of measured variables for forest structure in each forest type.

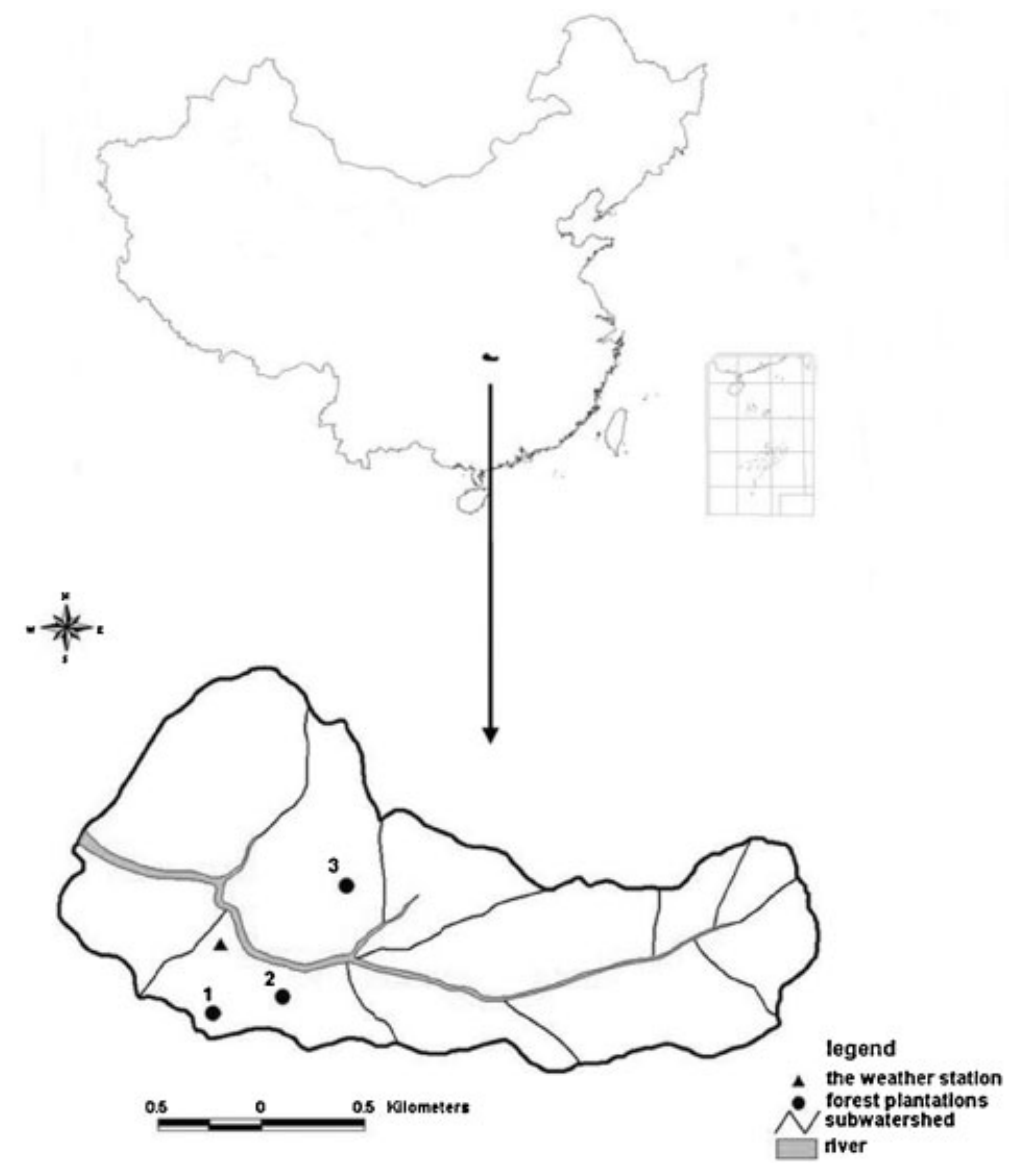

Figure 1. Location of the experimental site in southern China. 1: P.massoniana plantation; 2: E.ulmoides plantation; 3: V.fordii plantation. 
Table I. Chemical and physical characteristics of soils

\begin{tabular}{lccccccc}
\hline Horizon & Depth $(\mathrm{cm})$ & $\mathrm{pH}$ & Total C $(\%)$ & Total N $(\%)$ & $\mathrm{BD}\left(\mathrm{g} \mathrm{cm}^{3}\right)$ & Total porosity $(\%)$ & WHC $(\%)$ \\
\hline $\mathrm{A}$ & $0-10$ & 4.8 & 1.38 & 0.14 & 1.57 & 28.0 & $18 \cdot 2$ \\
$\mathrm{~B}$ & $10-40$ & 4.9 & 1.04 & 0.09 & 1.63 & 27.1 & $17 \cdot 0$ \\
\hline
\end{tabular}

Notes: BD, bulk density; WHC, water-holding capacity.

Table II. Characteristics of three forest types (values are presented as the mean \pm std)

\begin{tabular}{lccrrrrr}
\hline Tree species & Plant ha ${ }^{-1}$ & DBH $(\mathrm{cm})$ & $\begin{array}{c}\text { Crown area } \\
\text { per tree }\left(\mathrm{m}^{2}\right)\end{array}$ & $\begin{array}{c}\text { Crown } \\
\text { height }(\mathrm{m})\end{array}$ & $\begin{array}{c}\text { Tree } \\
\text { height }(\mathrm{m})\end{array}$ & $\begin{array}{c}\text { Canopy } \\
\text { cover }(\%)\end{array}$ & $\begin{array}{c}\text { Leaf area } \\
\text { index }\end{array}$ \\
\hline E.ulmoides & 6478 & $4.5 \pm 1.1 \mathrm{~b}$ & $2.7 \pm 0.4 \mathrm{c}$ & $3.4 \mathrm{~b}$ & $6.0 \mathrm{a}$ & $80 \%$ & 2.7 \\
V.fordii & 2000 & $7.3 \pm 2.1 \mathrm{c}$ & $14.5 \pm 3.8 \mathrm{a}$ & $3.0 \mathrm{~b}$ & $4.8 \mathrm{~b}$ & $65 \%$ & 3.1 \\
P.massoniana & 2628 & $9.2 \pm 3.4 \mathrm{a}$ & $7.0 \pm 1.2 \mathrm{~b}$ & $5.7 \mathrm{a}$ & $8.6 \mathrm{a}$ & $75 \%$ & 3.3 \\
\hline
\end{tabular}

Notes: DBH: diameter at breast height; numbers in the same column followed by the same letter are not significantly different at $p<0 \cdot 05$.

\section{Gross Precipitation (P)}

Gross precipitation $(\mathrm{P})$ was measured with tipping bucket rain gauges $(n=4)$, placed in an open area close to the studied stands.

\section{Throughfall (TF)}

Throughfall (TF) was measured using 40-50 polyethylene tanks per forest type. These polyethylene tanks with a diameter of $30 \mathrm{~cm}$ were installed $1.3-1.5 \mathrm{~m}$ above the ground. Throughfall per rainfall event is the mean throughfall of all collectors and represents that of the whole plot for individual rainfall events.

\section{Stemflow (SF)}

Stemflow (SF) was measured with polythene tubing collectors for 45 sample trees, which represent the range of diameters in each forest plantation. Stemflow $(\mathrm{mm})$ at plot level is derived by employing the following equation (Price and Carlyle-Moses, 2003):

$$
\mathrm{SF}=\mathrm{SF}_{\text {mean }} \times n / \mathrm{FA}
$$

where SF is stemflow (mm) for a given area of forest (FA) $\left(\mathrm{m}^{2}\right)$ with $n$ number of trees and $\mathrm{SF}_{\text {mean }}$ is the mean stemflow volume of the sample trees. Generally, we collected stemflow and throughfall within $6 \mathrm{~h}$ after a rainfall event from July 2004 to September 2005.

\section{Interception (I)}

As canopy interception loss cannot be measured directly, interception (I) is assumed to be the difference between gross precipitation measured in the open field and the sum of throughfall and stemflow obtained at plot level.

$$
\mathrm{I}=\mathrm{P}-(\mathrm{TF}+\mathrm{SF})
$$

where I is interception loss (mm), P is gross precipitation ( $\mathrm{mm})$, TF is throughfall (mm) and SF is stemflow $(\mathrm{mm})$ at plot level for individual rainfall events.

\section{Surface Runoff and Soil Loss}

Nine runoff plots (three plots per forest type, $10 \mathrm{~m} \times 10 \mathrm{~m}$ each) are located on a slope of $17-25^{\circ}$ and represent the three forest types in the study region. Before the plots were set, the soil condition was basically consistent. Surface runoff and soil loss were measured by estimating water and sediment collected after a single rainfall event from 2002 to 2005 . For estimation of the sediment loss, $500 \mathrm{~cm}^{3}$ of runoff water was sampled and filtered after homogenisation of the collected water, as soon as each runoff event ended. 


\section{Data Analysis}

Data were analysed statistically, using SPSS (version 10.0). ANOVA was used to compare the effects of different plantations on rainfall redistribution and erosion. All levels of statistical significance are considered at $p<0 \cdot 05$.

\section{RESULTS}

\section{Rainfall Characteristics}

Over the period July 2004 to September 2005, a total of $2086 \cdot 1 \mathrm{~mm}$ of gross precipitation was measured and 89 rainfall events were recorded. During this period, mean rainfall intensity was $3 \cdot 2 \mathrm{~mm} \mathrm{~h}^{-1}$ ranging from $0 \cdot 3$ to $14.7 \mathrm{~mm} \mathrm{~h}^{-1} ; 433.4 \mathrm{~mm}$ of the incident rain $(20.8 \%$ of gross precipitation) fell in single showers of less than $0.9 \mathrm{~mm} \mathrm{~h}^{-1}$. Showers of less than $5.0 \mathrm{~mm} \mathrm{~h}^{-1}$ contributed $81.8 \%$ of gross precipitation (Figure 2). Three large events $(>90.0 \mathrm{~mm})$ contributed $21.8 \%$ of gross precipitation, while 43 intermediate rainfall events $(10 \cdot 0-60 \cdot 0 \mathrm{~mm})$ accounted for $57 \cdot 3 \%$ of gross precipitation.

\section{Throughfall}

Total throughfall over the period July 2004 to September 2005 accounted for $72.5 \%, 75.6 \%$ and $70.4 \%$ of total gross rainfall for E.ulmoides, V.fordii and P.massoniana, respectively. Table III shows that the contribution of throughfall to gross rainfall was significantly correlated with rainfall amounts in each forest type, reaching a maximum in rainfall class $>100 \cdot 0 \mathrm{~mm}$.

For the five rainfall classes distinguished, spatial variability of throughfall in each forest plantation, expressed as a coefficient of variability (CV), was found to be highest for the rainfall class $<10 \cdot 0 \mathrm{~mm}$ and ranged from $16.7 \%$ to $40 \cdot 2 \%$. It was lowest for rainfall events $>100 \cdot 0 \mathrm{~mm}$ (range $=2 \cdot 7-7 \cdot 6 \%)$. Spatial variability in throughfall was highest in P.massoniana and lowest in V.fordii.

Table IV displays throughfall (\%) at the various stem distances. Using ANOVA, a significant effect of the tree species on throughfall was found for stem distances $<60 \mathrm{~cm}$ or $>120 \mathrm{~cm}$, but the difference in throughfall at stem distances $60-120 \mathrm{~cm}$ was not significant between the different forest types. Throughfall at a stem distance $<60 \mathrm{~cm}$ was 28.0-39.7\% higher for P.massoniana than for the other tree species. However, throughfall at a stem distance $>120 \mathrm{~cm}$ was $11.5 \%$ lower for P.massoniana than for the other tree species $(p<0.05)$. Throughfall at a stem distance $<60 \mathrm{~cm}$ was not significantly different between E.ulmoides and V.fordii (Table IV).
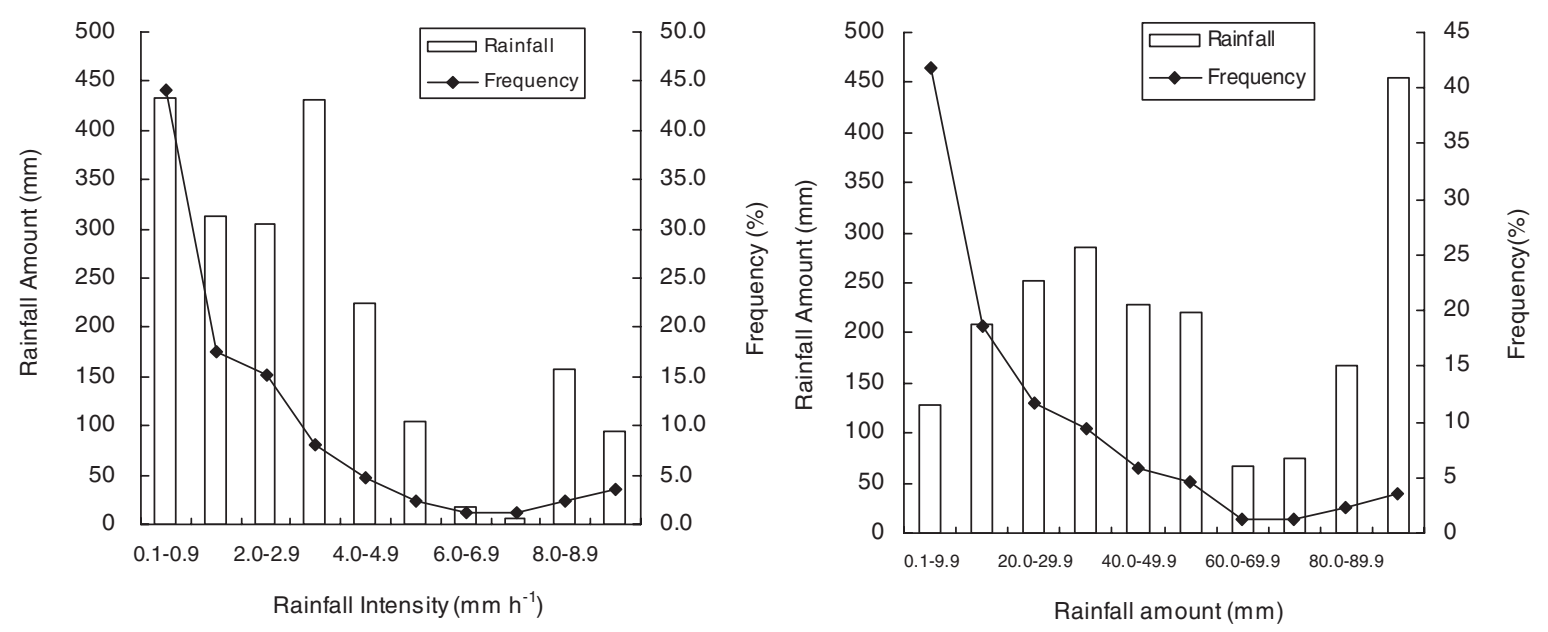

Figure 2. Rainfall characteristics of the study region (July 2004 to September 2005). 
Table III. Throughfall expressed as percentage of gross rainfall $(\%)$ for five rainfall classes in three forests

\begin{tabular}{|c|c|c|c|c|c|c|c|c|c|}
\hline \multirow[t]{2}{*}{ Rainfall class (mm) } & \multicolumn{3}{|c|}{ E.ulmoides } & \multicolumn{3}{|c|}{ V.fordii } & \multicolumn{3}{|c|}{ P.massoniana } \\
\hline & $\%$ & STD & $\mathrm{CV}$ & $\%$ & STD & $\mathrm{CV}$ & $\%$ & STD & $\mathrm{CV}$ \\
\hline$<10 \cdot 0$ & $46 \cdot 1$ & $10 \cdot 5$ & $22 \cdot 8$ & $57 \cdot 0$ & $9 \cdot 5$ & $16 \cdot 7$ & $41 \cdot 0$ & $16 \cdot 5$ & $40 \cdot 2$ \\
\hline $10 \cdot 0-24.9$ & $69 \cdot 4$ & $9 \cdot 6$ & $13 \cdot 8$ & $69 \cdot 4$ & $8 \cdot 8$ & $12 \cdot 7$ & $68 \cdot 6$ & $15 \cdot 1$ & $22 \cdot 0$ \\
\hline $25 \cdot 0-49 \cdot 9$ & $70 \cdot 2$ & $7 \cdot 3$ & $10 \cdot 4$ & $73 \cdot 2$ & $7 \cdot 8$ & $10 \cdot 7$ & 69.9 & $13 \cdot 1$ & $18 \cdot 7$ \\
\hline $50 \cdot 0-99 \cdot 9$ & $75 \cdot 8$ & $6 \cdot 1$ & $8 \cdot 0$ & $75 \cdot 2$ & $6 \cdot 4$ & $8 \cdot 5$ & $71 \cdot 8$ & $10 \cdot 0$ & 13.9 \\
\hline$>100 \cdot 0$ & $77 \cdot 0$ & $5 \cdot 4$ & $7 \cdot 0$ & $77 \cdot 8$ & $2 \cdot 1$ & $2 \cdot 7$ & $76 \cdot 5$ & $5 \cdot 8$ & $7 \cdot 6$ \\
\hline
\end{tabular}

Notes: STD: standard deviation; CV: coefficient of variability.

Table IV. Throughfall expressed as percentage of gross rainfall $(\%)$ at the various stem distances

\begin{tabular}{|c|c|c|c|c|c|c|}
\hline \multirow[t]{2}{*}{ Species } & \multicolumn{2}{|c|}{$0-60 \mathrm{~cm}$} & \multicolumn{2}{|c|}{$60-120 \mathrm{~cm}$} & \multicolumn{2}{|c|}{$>120 \mathrm{~cm}$} \\
\hline & $\%$ & STD & $\%$ & STD & $\%$ & std \\
\hline E.ulmoides & $55.9 \mathrm{~b}$ & $9 \cdot 2$ & $64.9 \mathrm{a}$ & $7 \cdot 5$ & - & - \\
\hline V.fordii & $61.0 \mathrm{~b}$ & $14 \cdot 1$ & $65 \cdot 4 \mathrm{a}$ & $5 \cdot 5$ & $68.7 \mathrm{a}$ & $7 \cdot 7$ \\
\hline P.massoniana & $78.1 \mathrm{a}$ & $18 \cdot 6$ & $65.5 \mathrm{a}$ & $11 \cdot 6$ & $61 \cdot 6 \mathrm{~b}$ & $5 \cdot 3$ \\
\hline
\end{tabular}

Notes: Values within columns followed by the same subscript letter are not significantly different at $p<0 \cdot 05$.

\section{Stemflow}

Total stemflow over the period July 2004 to September 2005 accounted for $7.6 \%$ of total gross rainfall in the E.ulmoides forest, $3.6 \%$ in the V.fordii forest and $2.4 \%$ in the P.massoniana forest. In rainfall class $50.0-99.9 \mathrm{~mm}$, stemflow reached a maximum for E.ulmoides $(8.0 \pm 1.7 \%)$ and P.massoniana $(3.2 \pm 0.3 \%)$, while stemflow in V.fordii reached a maximum $(4.0 \pm 1.0 \%)$ in rainfall class $25.0-49.9 \mathrm{~mm}$ (Table V). The amount of stemflow during a rainfall event was found to be highly variable among individual trees of the same species. Standard deviations (STD) of stemflow (\%) in E.ulmoides and P.massoniana were greater for small rainfall events than for large rainfall events, whereas in V.fordii the STD did not differ between different rainfall classes. ANOVA analysis showed that stemflow expressed as percentage of gross rainfall in E.ulmoides was significantly different from the other forest types $(p<0.05)$, while the difference in stemflow between V.fordii and P.massoniana was not significant $(p>0 \cdot 05)$.

To test the effect of tree crown on stemflow for the various species, we performed Pearson correlations for stemflow volume per mm of rainfall versus the projected area of the tree crown of the respective sample tree. The results show that stemflow $\left(\mathrm{cm}^{3} \mathrm{~mm}^{-1}\right)$ is statistically related to the projected area of the tree crown $(p<0 \cdot 05)$ (Figure 3$)$.

\section{Interception}

Interception loss was found to be closely related to rainfall amount. For each forest type, interception loss (mm) increased with increasing amount of rainfall (Table VI), but relative interception loss (the ratio of interception loss

Table V. Stemflow expressed as percentage of gross rainfall $(\%)$ for five rainfall classes in three forests

\begin{tabular}{|c|c|c|c|c|c|c|}
\hline \multirow[t]{2}{*}{ Rainfall class (mm) } & \multicolumn{2}{|c|}{ E.ulmoides } & \multicolumn{2}{|c|}{ V.fordii } & \multicolumn{2}{|c|}{ P.massoniana } \\
\hline & $\%$ & STD & $\%$ & STD & $\%$ & STD \\
\hline$<10 \cdot 0$ & $7 \cdot 0$ & $2 \cdot 7$ & $3 \cdot 2$ & $1 \cdot 0$ & 0.9 & $1 \cdot 0$ \\
\hline $10 \cdot 0-24 \cdot 9$ & $7 \cdot 8$ & 1.9 & $3 \cdot 6$ & $1 \cdot 1$ & $1 \cdot 6$ & 0.9 \\
\hline $25 \cdot 0-49 \cdot 9$ & $7 \cdot 8$ & 1.9 & $4 \cdot 0$ & $1 \cdot 0$ & $2 \cdot 3$ & 0.7 \\
\hline $50 \cdot 0-99 \cdot 9$ & $8 \cdot 0$ & $1 \cdot 7$ & $3 \cdot 5$ & $1 \cdot 0$ & $3 \cdot 2$ & $0 \cdot 3$ \\
\hline$>100 \cdot 0$ & $7 \cdot 1$ & $1 \cdot 0$ & $3 \cdot 0$ & $1 \cdot 1$ & $2 \cdot 7$ & $0 \cdot 3$ \\
\hline
\end{tabular}

Notes: STD: standard deviation. 


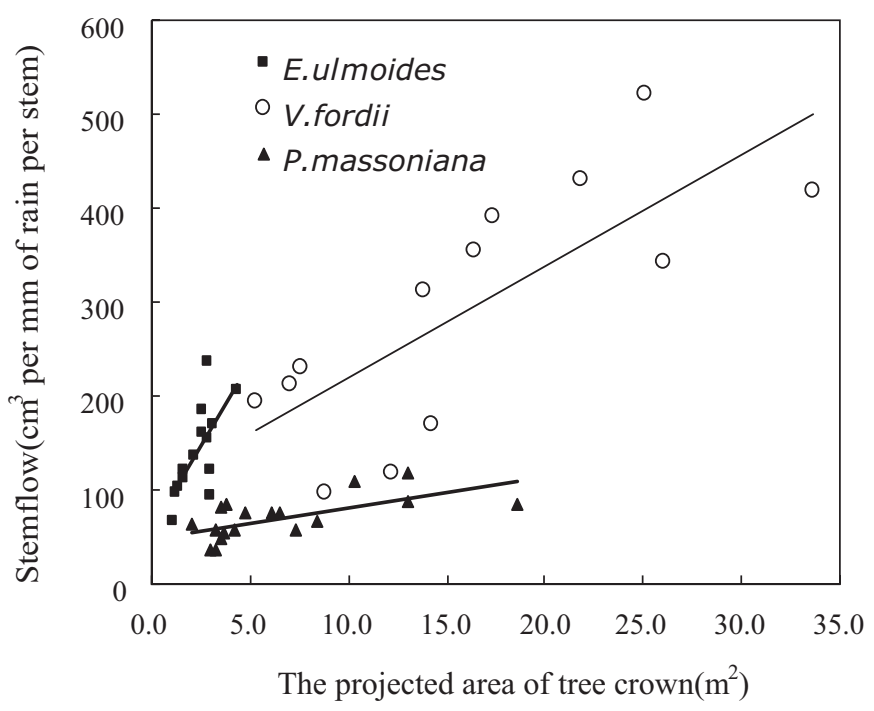

Figure 3. Relationship between the projected area of the tree crown and individual stemflow for the three tree species.

to gross rainfall) decreased with increasing amount of rainfall (Figure 4). Interception loss expressed as percentage of gross rainfall varied from $15.9 \pm 4 \cdot 2 \%$ to $58 \cdot 1 \pm 17 \cdot 0 \%$ in the three forest plantations, depending on rainfall amounts and forest types. For small rain events $(<10.0 \mathrm{~mm})$, interception loss expressed as percentage of gross rainfall was highest in each forest type (Table VI). For large rain events $(>100.0 \mathrm{~mm})$, however, interception loss expressed as percentage of gross rainfall was $15.9 \%$ for E.ulmoides, $19.2 \%$ for V.fordii and $21.8 \%$ for P.massoniana. Interception loss was statistically different among the three forest types at the $95 \%$ confidence level. Over the whole measurement period, interception expressed as percentage of total gross rainfall was highest for P.massoniana (27.2\%) and lowest for E.ulmoides (19.9\%).

\section{Rainfall Redistribution}

Table VII shows the characteristics of rainfall redistribution in each forest type. Over the measurement period, $80.1 \%$ of gross rainfall was transformed into throughfall and stemflow for E.ulmoides, of which $90.5 \%$ arrived as throughfall and $9.5 \%$ as stemflow. For V.fordii, throughfall plus stemflow accounted for $79.2 \%$ of gross rainfall, of which $95.5 \%$ arrived as throughfall and $4.5 \%$ as stemflow. Throughfall plus stemflow underneath P.massoniana was lowest (72.8\% of gross rainfall), which included $96.7 \%$ as throughfall and $3.3 \%$ as stemflow. Throughfall accounted for more than $90 \%$ of net precipitation and obviously controlled the water input below the canopy.

\section{Soil Loss and Runoff Response}

During the period 2002-2005, 84 runoff events were recorded. Correlations between runoff or soil loss and rainfall were statistically significant for the three forests. Moreover, runoff and soil loss increased as rainfall amounts

Table VI. Interception expressed as percentage of gross rainfall $(\%)$ for five rainfall classes in three forests

\begin{tabular}{|c|c|c|c|c|c|c|}
\hline \multirow[t]{2}{*}{ Rainfall class (mm) } & \multicolumn{2}{|c|}{ E.ulmoides } & \multicolumn{2}{|c|}{ V.fordii } & \multicolumn{2}{|c|}{ P.massoniana } \\
\hline & $\%$ & std & $\%$ & STD & $\%$ & STD \\
\hline$<10 \cdot 0$ & $46 \cdot 9$ & $12 \cdot 8$ & $39 \cdot 8$ & 8.9 & $58 \cdot 1$ & $17 \cdot 0$ \\
\hline $10 \cdot 0-24 \cdot 9$ & $22 \cdot 8$ & $18 \cdot 3$ & $27 \cdot 0$ & $18 \cdot 8$ & $29 \cdot 8$ & $21 \cdot 0$ \\
\hline $25 \cdot 0-49 \cdot 9$ & $22 \cdot 0$ & $6 \cdot 7$ & $22 \cdot 8$ & $7 \cdot 7$ & $27 \cdot 8$ & $13 \cdot 3$ \\
\hline $50 \cdot 0-99 \cdot 9$ & $16 \cdot 2$ & $7 \cdot 3$ & $21 \cdot 3$ & $7 \cdot 1$ & $25 \cdot 0$ & $10 \cdot 0$ \\
\hline$>100 \cdot 0$ & $15 \cdot 9$ & $4 \cdot 2$ & $19 \cdot 2$ & $2 \cdot 9$ & $20 \cdot 8$ & $7 \cdot 2$ \\
\hline
\end{tabular}



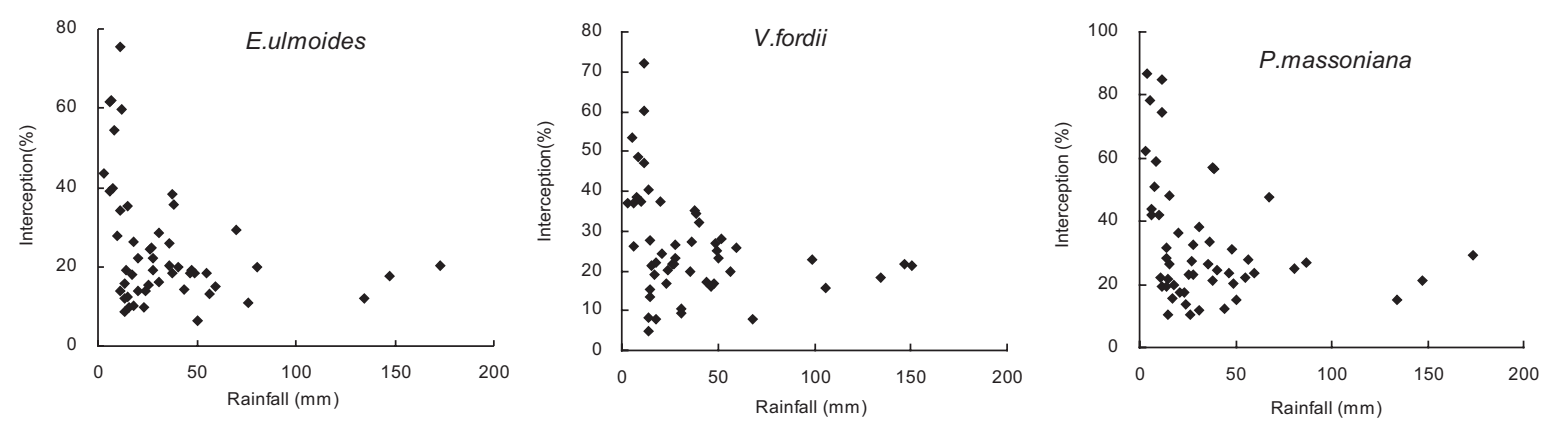

Figure 4. Relationship between relative interception loss $(\%)$ and gross rainfall $(\mathrm{mm})$ in three forests.

increased (Figure 5). Runoff and soil loss for V.fordii differed significantly $(p<0.05)$ from the other types of forest plantations, while the difference between E.ulmoides and P.massoniana was not statistically significant during the study period. Over the period 2002-2005, the mean annual runoff coefficient and total soil loss varied considerably (Figure 6). The highest runoff coefficient was found for the V.fordii forest (4.2\%), while the lowest runoff coefficient was $2.1 \%$ from the P.massoniana forest. During the 4-year period, the total soil loss was $63 \cdot 7,22 \cdot 1 \mathrm{and} 19 \cdot 6 \mathrm{t} / \mathrm{km}^{2}$ for V.fordii, E.ulmoides and P.massoniana, respectively. Thus, the V.fordii forest yielded the highest runoff and soil loss, while the P.massoniana forest yielded the lowest erosion among the three types of forest plantations.

\section{DISCUSSSION}

\section{Throughfall}

During the study period, throughfall and gross rainfall were highly correlated for each forest type, and throughfall ranged from $70.4 \%$ to $75.6 \%$ of gross rainfall which fell within the range of mean values $(58 \cdot 0-82.7 \%)$ reported for different forest types (Návar et al., 1999; Tobón-Marin et al., 2000; Xiao et al., 2000).

Our results also indicated that the variability of throughfall for all forests decreased with increasing rainfall amounts, which was consistent with observations by other researchers (Loustau et al., 1992; Llorens et al., 1997; Tobón-Marin et al., 2000). Differences in throughfall were significant at stem distances $<60 \mathrm{~cm}$ or $>120 \mathrm{~cm}$, while the difference in throughfall at stem distances $60-120 \mathrm{~cm}$ was not significant. Significant spatial variation in throughfall was observed below the canopy, as reported by others (Schroth et al., 1999; Jackson, 2000). For E.ulmoides, throughfall under the peripheral crown part was $16 \cdot 1 \%$ higher than that close to the stem (Figure 7). In contrast to E.ulmoides, P.massoniana had 26.8\% lower throughfall under the peripheral crown parts than close to the stem. But there was not significant difference in throughfall between the various stem distances underneath V.fordii.

\section{Stemflow}

In many studies on rainfall redistribution, the contribution of stemflow to gross rainfall appeared to be very low and less than $3.0 \%$ of gross precipitation reached the forest floor as stemflow. Therefore, it was generally assumed to be a negligible component of the hydrological cycle (Lloyd and Marques, 1988; Taniguchi et al., 1996; Tobón-Marin et al., 2000). However, some studies found that stemflow from particular tree species could be as high as 5.0\% or

Table VII. Characteristics of rainfall redistribution (mean \pm std) for the period July 2004 to September 2005

\begin{tabular}{|c|c|c|c|c|c|c|c|}
\hline Species & $\mathrm{TF} \%$ & $\mathrm{SF} \%$ & Individual $\mathrm{SF}\left(\mathrm{cm}^{3} \mathrm{~mm}^{-1}\right)$ & Net precipitation (NP)\% & $\mathrm{TF} / \mathrm{NP} \%$ & $\mathrm{SF} / \mathrm{NP} \%$ & I $\%$ \\
\hline E.ulmoides & $72 \cdot 5$ & $7 \cdot 6$ & $125 \cdot 8 \pm 21 \cdot 4$ & $80 \cdot 1$ & $90 \cdot 5$ & $9 \cdot 5$ & $19 \cdot 9$ \\
\hline V.fordii & $75 \cdot 6$ & $3 \cdot 6$ & $286 \cdot 0 \pm 54 \cdot 1$ & $79 \cdot 2$ & $95 \cdot 5$ & $4 \cdot 5$ & $20 \cdot 8$ \\
\hline P.massoniana & $70 \cdot 4$ & $2 \cdot 4$ & $80 \cdot 5 \pm 23 \cdot 0$ & $72 \cdot 8$ & $96 \cdot 7$ & $3 \cdot 3$ & $27 \cdot 2$ \\
\hline
\end{tabular}

Notes: throughfall (TF), stemflow (SF), interception (I); TF\%, SF\%, I\%, the ratio of throughfall, stemflow and interception to gross rainfall; individual SF, individual stemflow volume per mm of rainfall; Net precipitation (NP), the sum of throughfall and stemflow; NP\%, throughfall plus stemflow expressed as percentage of gross rainfall. 

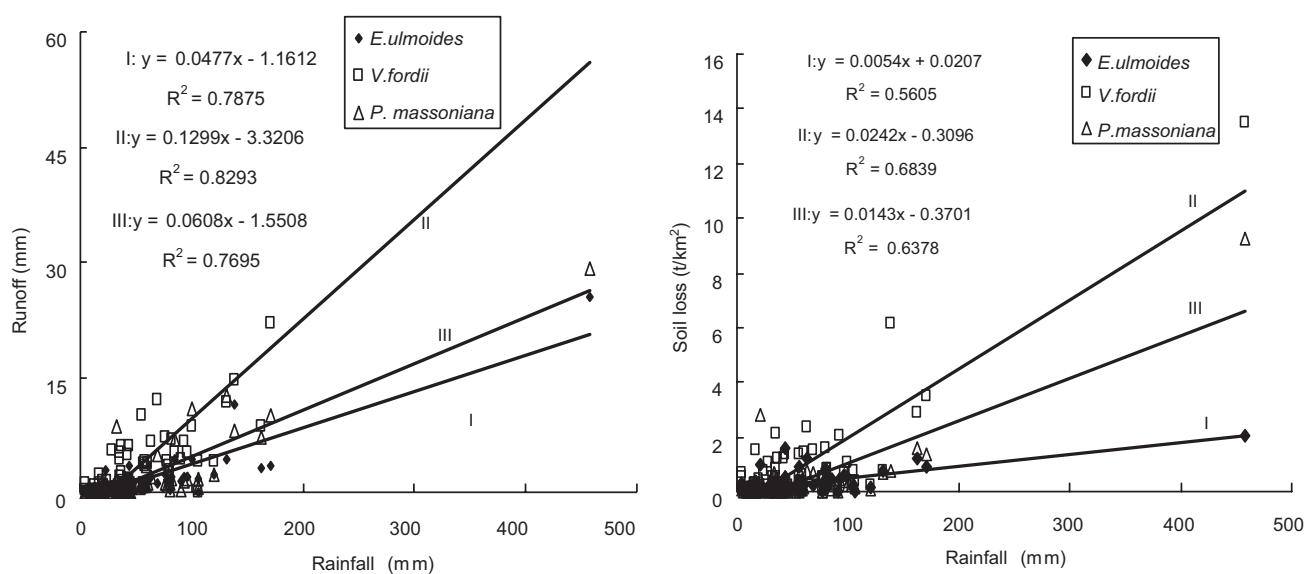

Figure 5. Relationship between runoff or soil loss and rainfall for the three forest types.

even $>10.0 \%$ of gross precipitation (Clements, 1971; Herwitz and Levia, 1997; Xiao et al., 2000). In our study, stemflow ranged from $2.4 \%$ to $7.6 \%$ of gross rainfall. And stemflow in E.ulmoides was significantly different from the other forest types $(p<0 \cdot 01)$. Moreover, the difference in individual stemflow volume was significant among the same tree species. We also found that the relationship between individual stemflow volume and the projected area of tree crown was statistically significant for each forest type.

The amount of stemflow (mm) increased when rainfall increased in all forest types. This is consistent with many previous studies that reported stemflow as a function of gross rainfall on a rainfall-event basis (Schroth et al., 1999; Tobón-Marin et al., 2000; Price and Carlyle-Moses, 2003). Although stemflow was a small fraction of the total rainfall that reached the soil, stemflow concentrates water in a small area around the tree trunk, resulting in an increase in soil moisture far greater than that due to throughfall (Herwitz, 1986; Gómez et al., 2002; Levia and Frost, 2003).

\section{Interception}

Defined as water being intercepted, stored and subsequently evaporated from leaves, branches and stems of vegetation, interception loss accounts for the difference between gross rainfall and the sum of throughfall and

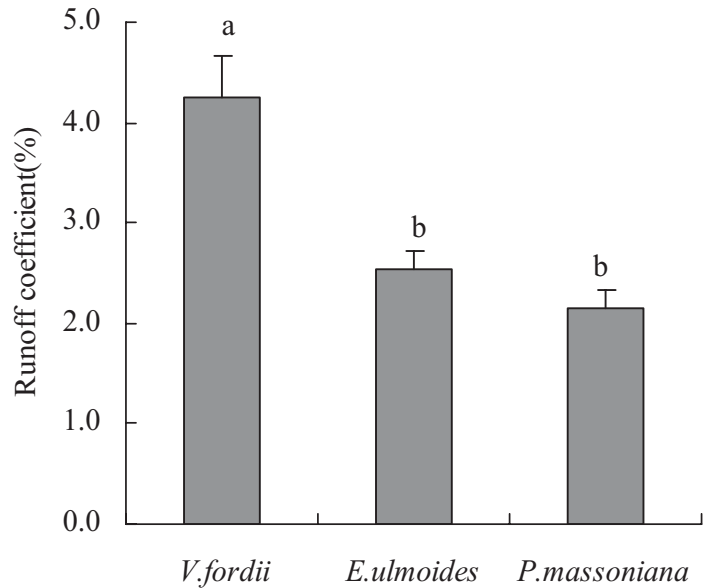

Forest plantations

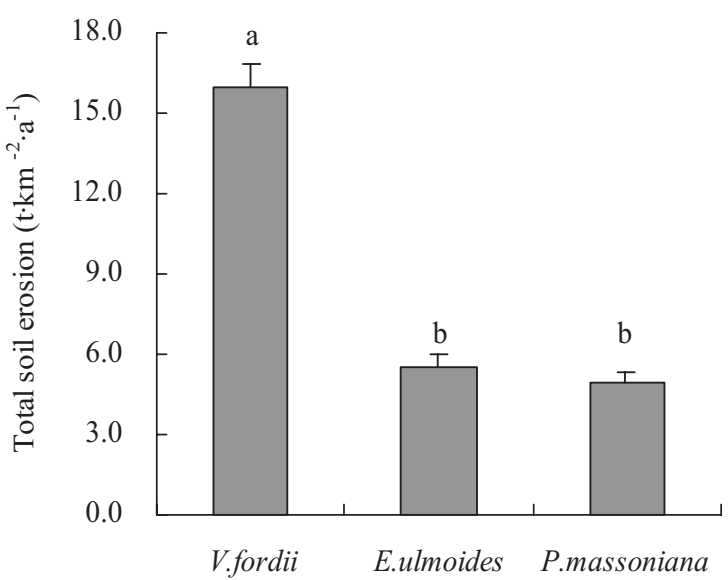

Forest plantations

Figure 6. Mean annual runoff coefficient and total soil loss during the 4-year period. Column with different letters are significantly different at the $95 \%$ level. Vertical bars, standard error. 


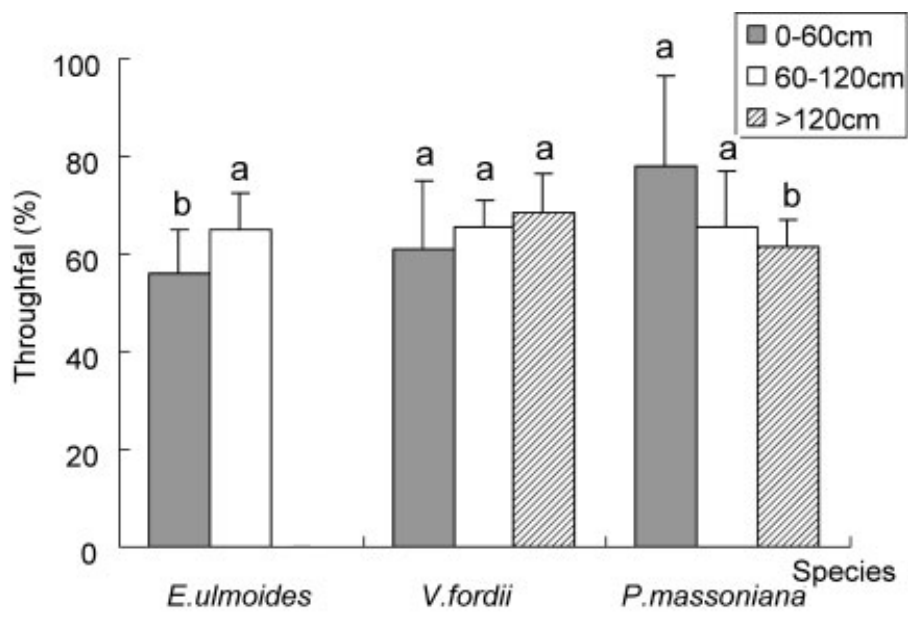

Figure 7. Throughfall expressed as percentage of gross rainfall $(\%)$ at the various stem distances. Column with different letters for the same species are significantly different at the $95 \%$ level. Vertical bars, standard error.

stemflow. It is a significant component in the forest water cycle (Schellekens et al., 2000; Xiao et al., 2000). As a general trend, interception is influenced by rainfall types and forest characteristics (Tobón-Marin et al., 2000). During the study period, interception loss $(\mathrm{mm})$ increased with increasing rainfall amounts, but interception expressed as percentage of gross rainfall $(\%)$ decreased with increasing rainfall amounts. These findings are consistent with those in other studies (Llorens et al., 1997; Price et al., 1997; Xiao et al., 2000). Interception loss by different forest types followed similar trend to rainfall amounts, but of different magnitudes (Schroth et al., 1999; Tobón-Marin et al., 2000; Xiao et al., 2000). Over the whole measurement period, interception loss by P.massoniana was significantly higher than that by the other forests $(p<0 \cdot 01)$.

Owing to interception, net precipitation (throughfall plus stemflow) below the forest canopy accounted for $72.8 \%$ to $80.1 \%$ of gross rainfall over the period July 2004 to September 2005. Among the three forest types, net precipitation in the P.massoniana forest was lowest. Moreover, the P.massoniana forest had the lowest runoff and soil loss. Different forest types do impose significant impacts on rainfall redistribution, surface runoff and soil erosion (Carlyle-Moses, 2004; Vega et al., 2005), but the P.massoniana forest has the best results with regard to soil and water conservation among the three types of forest plantations.

\section{CONCLUSIONS}

The data presented provide insight into the variability of rainfall redistribution for three major types of forest plantations. Throughfall over the period July 2004 to September 2005 accounted for $72.5 \%$ of gross rainfall for E.ulmoides, $75.6 \%$ for V.fordii and $70.4 \%$ for P.massoniana. Throughfall at stem distances $<60 \mathrm{~cm}$ or $>120 \mathrm{~cm}$ differed significantly among the three forest types $(p<0 \cdot 05)$. For E.ulmoides, throughfall under the peripheral crown part was $16.1 \%$ higher than that close to the stem. In contrast, for P.massoniana, throughfall under the peripheral crown part was $26.8 \%$ lower than that close to the stem. However, throughfall in V.fordii did not differ significantly between the various stem distances $(p>0.05)$. Throughfall coefficients of variability for small rainfall events were greater than those for large rainfall events.

Stemflow over the measurement period accounted for $7.6 \%$ of gross rainfall for E.ulmoides, $3.6 \%$ for V.fordii and $2.4 \%$ for P.massoniana. Stemflow in E.ulmoides was significantly higher than that in the other forests $(p<0 \cdot 01)$, while the difference in stemflow between V.fordii and P.massoniana was not significant $(p>0 \cdot 05)$. Interception loss accounted for $19.9 \%$ of gross rainfall for E.ulmoides, $20.8 \%$ for V.fordii and $27.2 \%$ for P.massoniana. Interception among the three forest types also differed significantly $(p<0 \cdot 05)$. Moreover, relative interception loss (the ratio of interception loss to gross rainfall) decreased with increasing amount of rainfall for each forest type. 
For the three forest plantations, throughfall plus stemflow represented more than $70.0 \%$ of gross rainfall. Throughfall accounted for more than $90 \%$ of net precipitation, and obviously dominated the water input below the canopy. All three types of forest plantations could decrease erosion, but there were significant differences in runoff and soil loss between the three forest types. Annual runoff and total soil loss were lowest in P.massoniana and highest in V.fordii during the measurement period.

\section{ACKNOWLEDGEMENTS}

This research was sponsored by the National Natural Science Foundation of China (30230090) and the Innovation Group Project of the National Natural Science Foundation of China "40621061". The author thanks the anonymous referee for valuable comments that allowed improving the quality of this manuscript.

\section{REFERENCES}

Carlyle-Moses DE. 2004. Throughfall, stemflow, and canopy interception loss fluxes in a semi-arid Sierra Madre Oriental matorral community. Journal of Arid Environments 58: 181-202.

Clements JR. 1971. Evaluating summer rainfall through a multilayered largetooth aspen community. Canadian Journal of Forest Research 1: $20-31$.

Gong ZT (ed.). 1999. Chinese Soil Taxonomy. Science Press: Beijing; p. 676. (in Chinese).

Gómez JA, Vanderlinden K, Giraldez JV, Fereres E. 2002. Rainfall concentration under olive trees. Agricultural water management 55: 53-70.

Hanson DL, Steenhuis TS, Walter MF, Boll J. 2004. Effects of soil degradation and management practices on the surface water dynamics in the Talgua river watershed in Honduras. Land Degradation \& Development 15: 367-381.

Herwitz SR. 1986. Infiltration-excess caused by stemflow in a cyclone-prone tropical rainforest. Earth Surface Processes and Landforms 11: $401-412$.

Herwitz SR, Levia DF Jr. 1997. Mid-winter stemflow drainage from bigtooth aspen (Populus grandidentata michx.) in central Massachusetts. Hydrological Processes 11: 169-175.

Jackson NA. 2000. Measured and modeled rainfall interception loss from an agroforestry system in Kenya. Agricultural and Forest Meteorology 100: $323-336$.

Levia DF Jr, Frost EF. 2003. A review and evaluation of stemflow literature in the hydrologic and biogeochemical cycles of forested and agricultural ecosystems. Journal of Hydrology 274: 1-29.

Llorens P, Poch R, Latron J, Gallart F. 1997. Rainfall interception by a Pinus sylvestris forest patch overgrown in a Mediterranean mountainous abandoned area. I. Monitoring design and results down to the event scale. Journal of Hydrology 199: 331-345.

Lloyd CR, Marques FAO. 1988. Spatial variability of throughfall and stemflow measurements in Amazonian rain forest. Agricultural and Forest Meteorology 42: 63-73.

Loustau D, Berbigier P, Granier A. 1992. Interception loss, throughfall and stemflow in a maritime pine stand. I. Variability of throughfall and stemflow beneath the pine canopy. Journal of Hydrology 138: 449-467.

Návar J, Charles F, Jurado E. 1999. Spatial variations of interception loss components by Tamaulipan thornscrub in northeastern Mexico. Forest Ecology and Management 124: 231-239.

Price AG, Carlyle-Moses DE. 2003. Measurement and modeling of growing-season canopy water fluxes in a mature mixed deciduous forest stand, southern Ontario, Canada. Agricultural and Forest Meteorology 119: 69-85.

Price AG, Dunham K, Carleton T, Band L. 1997. Variability of water fluxes through the black spruce (Picea mariana) canopy and feather moss (Pleurozium schreberi) carpet in the boreal forest of Northern Manitoba. Journal of Hydrology 196: 310-323.

Schellekens J, Bruijnzeel LA, Scatena FN, Bink NJ, Holwerda F. 2000. Evaporation from a tropical rain forest, Luquillo Experimental Forest, Eastern Puerto Rico. Water Resources Research 36: 2183-2196.

Schroth G, da Silva LF, Wolf MA, Teixeira WG, Zech W. 1999. Distribution of throughfall and stemflow in multi-strata agroforestry, perennial monoculture, fallow and primary forest in central Amazonia, Brazil. Hydrological Processes 13: 1423-1436.

Taniguchi M, Tsujimura M, Tanaka T. 1996. Significance of stemflow in groundwater recharge.1: Evaluation of the stemflow contribution to recharge using a mass balance approach. Hydrological Processes 10: 71-80.

Tobón-Marin C, Bouten W, Sevink J. 2000. Gross rainfall and its partitioning into throughfall, stemflow and evaporation of intercepted water in four forest ecosystems in western Amazonia. Journal of Hydrology 237: 40-57.

Vega JA, Fernández C, Fonturbel T. 2005. Throughfall, runoff and soil erosion after prescribed burning in gorse shrubland in Galicia (NW Spain). Land Degradation \& Development 16: 37-51.

Xiao QF, McPherson EG, Ustin SL, Grismer ME, Simpson JR. 2000. Winter rainfall interception by two mature open-grown trees in Davis, California. Hydrological Processes 14: 763-784.

Zhang B, Yang YS, Zepp H. 2004. Effect of vegetation restoration on soil and water erosion and nutrient losses of a severely eroded clayey Plinthudult in southeastern China. Catena 57: 77-90.

Zhao QG (ed.). 2002. The Red Soil Material Cycling and its Regulation. Science Press: Beijing (in Chinese).

Zhou GY, Morris JD, Yan JH, Yu ZY, Peng SL. 2002a. Hydrological impacts of reafforestation with eucalypts and indigenous species: a case study in southern China. Forest Ecology and Management 167: 209-222.

Zhou GY, Wei XH, Yan JH. 2002b. Impacts of eucalyptus (Eucalyptus exserta) plantation on sediment yield in Guangdong Province, Southern China-a kinetic energy approach. Catena 49: 231-251. 